\title{
AGING IDENTITY: DO THEORIES MATCH EXPERIENCES?
}

GRAŽINA RAPOLIENE ${ }^{l}$

\begin{abstract}
Dominant aging identity theories ("mask of ageing", "social mask", M. Foucault's "disembodiment thesis", gerotranscendental theory) as well as the concept of the postmodern reflexive self of A. Giddens cannot be used to effectively explain old age identity in contemporary Lithuania. More suitable for this purpose is E. Goffman's concept of stigma that explains denial, evasion and marginalization of old age.

These are the conclusions of a qualitative piece of research - involving in-depth interviews with elderly people - that was designed to examine the ways in which old age identity is created and aging is experienced by older people, as well as to ascertain whether the elderly experience stigmatization in everyday interactions. The data were collected from October 2010 - January 2011 in Vilnius $(\mathrm{N}=24)$ : the selection of informants was targeted by gender, age group (60-74 and 75-89), level of education (primary, secondary, higher), and household type (households of several generations, single-generation and institutional households). To interpret the data, the method of abduction or inference to the best explanation (Harman, 1965) was used.
\end{abstract}

KEYWORDS: aging identity, stigma, qualitative research

\section{THE THEORETICAL PERSPECTIVE ON OLD AGE IDENTITY}

Usually, aging identity is analyzed from two perspectives:

1. The definition of Self through activity, production or consumption. In the case of production, the Self is defined according to professional roles and

1 Gražina Rapolienè, Ph.D., is lecturer at Vilnius University; e-mail: g.rapoliene@gmail.com. The author thanks Prof. Zenonas Norkus and Prof. Sarmite Mikulionienè for comments and remarks. 
social status; accordingly, retirement infers the loss of a role, a lack of position in society and a crisis of identity. In the case of consumption, the Self is created through choosing a life style;

2. The relationship between Self and the body. "Old age mask" theory highlights a contradiction between a stable youthful inner Self and a negatively-perceived physical decline, or the body as a cage. The "masquerade" theory emphasizes maturing inner Self, age representation through different masks and the negotiation of age identity (MachatFrom, 2010).

The relationship to production or consumption distinguished in the first instance relates at the same time to a divide between modern and postmodern society. Modernist social gerontology mostly focuses on the relationship of individuals to work, which produces value that is accumulated for later in life (Phillipson, 1982), as well as on the "structural dependency" of individuals, expressed in the analysis of social classes. At the same time, the postmodernist paradigm of social gerontology focuses on understanding age identity, the body, the cultural representation of aging and aging images. It seeks to show the emergence of a new reality, including an understanding of the ageing body and the relationship of the body to consumer culture (Featherstone \& Wernick, 1995); thus, the problem of ageing identity becomes a problem of lifestyle choice and the construction of identity, shifting responsibility to the individual.

Postmodern aging theories such as "old age mask" theory devised by M. Featherstone and M. Hepworth (1990, 1991, 1993), attributed by L.MachatFrom (2010) to the second theoretical perspective (to the relationship between Self and body), emphasize the importance of the body, insisting on the existence of a tension between the surface of the aging person - face, body, decreases in functional capacity - and the youthful inner sense of Self. The signs of aging are described as a "mask, which cannot be removed: any connection they may have with the individual's personal sense of identity is the result of the ways other people react to changes in facial appearance and the social category they imply" (Featherstone, Hepworth, 1990:255). The aging body becomes an increasingly inflexible 'mask', which makes it more and more difficult to see the youthful Self behind it. According to M. Featherstone and M. Hepworth (1993:148), the old age mask "conceals the essential identity of the person beneath"; i.e., although external appearance changes with age, it does not touch the "inner or subjective "real self", which paradoxically remains young" (Hepworth, 1991: 93). The aging "outer body can be interpreted as a betrayal of the youthfulness of the inner body" (Turner, 1995: 257).

The idea of "masquerade" (Woodward, 1991) as well as the concepts of "persona" or "social mask" (Biggs, 1993, 1997) involve a somewhat reversed 
focus: a youthful mask protects an aging individual from a hostile society. The social mask is used "to protect the self and deceive others" (Biggs, 1999:76). "Both men and women "put on" youth so as not to be classified as old" (Woodward, 1991:159). Accordingly, there is a match between the subjective experience of aging and the aging of the body; however, the surrounding environment pressures one to develop a socially-acceptable image, which hinders self-expression. Bodily signs of aging, which others negatively appraise, obstruct people from greater involvement in a consumer way of life (Schwaiger, 2006; Biggs, 1997; Phillipson, Biggs, 1998), and at the same time from participation in social life.

Thus, wherever the main tensions are identified - between a youthful Self and a "betraying" body or between the harmonious aging of an individual and an ageist society - the aging body anyhow remains at the epicenter of such tension.

\section{THE BODY AS THE PIVOT OF IDENTITY}

Why is the body important in society? According to A. Giddens (1993), it has become a part of modern reflexivity; this means there is more and more reflexive interest in its regimes and its regulation of sensuality, and both life planning and life style choices (in principle) are integrated into bodily regimes (Giddens, 1993:102). In A. Giddens' opinion, it would be shortsighted to evaluate this phenomenon as a change in the ideals of body appearance (for example, grace and youthfulness) or to assume that it is caused by the influence of consumer advertising. We become responsible for the construction of our bodies; the more post-traditional are the social contexts in which we live, the more forced we are to do so.

Although the body is directly subordinated to the principle that Self can and should be constructed, in no way it has become an inert derivative, only a subject of commodification or "discipline", as perceived by M. Foucault. "In conditions of high modernity, the body is actually far less "docile" than ever before in relation to the self, since the two become intimately coordinated within the reflexive project of self-identity" (Giddens, 1993:218). Thus, in late modernity (or postmodernity) the importance of the body increases: it is increasingly integrated into the reflexive project of the Self. The importance of the body emphasized by A. Giddens resonates with "old age mask" theory and partly explains why aging identity issues have become relevant in the postmodern context.

M. Foucault (1988) provides an alternative view of old age: as a positive goal of existence, which should be aspired to. He affirms that "a human being 
turns him- or herself into a subject" through practices in which individuals "act on their own bodies, souls, thoughts, conduct, and way of being in order to transform themselves and attain a certain state of perfection or happiness, or to become a sage or immortal" (Foucault 1988; 3-4). Since the principle of self-knowledge evolved historically through the self-care approach, the highest form of self-care can be achieved in old age when the ability for physical pleasure and its desire or pursuit is lost. The perspective of M. Foucault is interesting as it suggests that old age is a process of decoupling from the body; a time when the subject increasingly identifies with the inner Self, as if refusing one's body.

It is important to note that all the theories - "old age mask", "social mask" and "masquerade", and M. Foucault's old age concept - suggest that individuals do not accept the cultural representation of aging. This acceptance infers the recognition of "aging mask", a threat to positive personal identity and positive self-esteem and advances reconciliation with unfavorable and marginalized positions in society: research confirms the behavior of the elderly in avoiding old age identification and analyzes the psychological strategies used for this purpose (George, 1998). The concept of A. Giddens could be used to offset this view of the denial of the aging body: a person in postmodernity seeks to know one's body, to integrate it into a reflexively-created Self identity and refine it. However, could the reflexive Self project include bodily aging, which is culturally associated with decline and is identified with disease? A. Giddens' theory does not consider specific cases.

\section{E. GOFFMAN'S CONCEPTION OF STIGMA}

Surprisingly, however, the context of aging identity does not give reference to E. Goffman's (1986 [1963]) concept of stigma. A stigma describes the situation of an individual for whom full social acceptance is inaccessible: if stigmatized, the person is considered different from normal people, as if not fully human, and is discriminated against in various ways, often unconsciously. Old age as one of the stigmata is discussed by Gerhard Falk (2001). He refers to E. Durkheim's theories of crime and deviation. In my opinion, such a linkage is not quite correct in the case of old age. According to E. Goffman, a stigma is a deviation that does not occur due to the violation of behavioral norms but rather arises due to personal features that (shamefully) do not conform to public norms (primarily, those of appearance), standards or stereotypes. 
Stigma is not concerned with undesirable features, but rather those that are incompatible with the stereotype applicable to an individual of a particular category. The focus in this case is not on characteristics, but on relationships. The feature itself is neither discreditable nor honorable because it may be stigmatizing for people in one category, but prove their conventionality in the case of another; for example, an employee's 'excess' qualifications might be kept secret at a certain workplace. In other words, a stigma is "a special kind of relationship between attribute and stereotype" (Goffman, 1986: 4). Since stereotypes are generally applied to a relatively broad category, a stigma belongs to public life and, first of all, to contacts with strangers (Goffman, 1986).

E. Goffman (1986:128) considers stigma a universal phenomenon and a form of deviance from identity norms. He uses the term "norm" in a broader sense to include a set of specific features hegemonic to a particular society (for example, vision, literacy or physical attractiveness), to which an individual must conform (rather than comply). Conformity to these norms has a direct impact on the psychological integrity of an individual. However, it is not always that an individual has the opportunity to conform to a norm, as it is not enough to only have the will or desire. As E. Goffman suggests, the norm in American society involves a young man who is married, white, urban, northern, heterosexual, a Protestant, a father, has a college education, is fully employed, is in good shape, weight and height, and is athletic. Anyone who does not conform to this norm feels unworthy, incomplete or miserable, if not for any other reason than because of their advancing old age (Goffman, 1986: 129). Thus, there is no sense in asking whether a person has experienced any stigma because s/he definitely will have; it is only worth asking how many variations of stigma one experiences during one's life (Goffman, 1986:129). Consequently, the effort to be younger is an attempt to replace a discredited old age stigma with a discreditable one. Stigma denial and concealment is particularly difficult if one becomes stigmatized late in life, having already internalized social attitudes with respect to the stigmatized. Therefore, there is a tendency to stratify the similarly stigmatized according to the level of noticeability of the stigma, and to hold depreciatory attitudes about the more evidently stigmatized.

Was E. Goffman right to ascribe old age to types of stigma? Does aging really spoil one's identity? Which theory best explains the experiences of elderly people? Peter Öberg (2003:126-129) emphasized the need to distinguish between dominant cultural values, the representation and the subjective experience of ageing because problems of old age such as loneliness, a low level of life satisfaction or the trauma of retirement, which are usually 
discussed in gerontology, do not correspond to actual experiences of ageing. There is an evident lack of qualitative research about the ageing experience which would reveal the meaning given to aging by older people themselves (Öberg, 2003:129). The research described in this paper was undertaken to fill this gap.

\section{THE MEANING OF OLD AGE (AGING) AND ITS SIGNIFICANCE FOR THE IDENTITY OF OLDER PEOPLE (QUALITATIVE RESEARCH)}

Methodology. The most appropriate name for the methodological approach to qualitative research conducted by the author would be abduction (Dey, 2004) or deductive inference to the best explanation (Harman, 1965) since the research guidelines were based on an analysis of theoretical concepts that seeks to distinguish the one that best explains reality. Since the goal of this study was to explore the aging experience - what does it mean to grow old, to be old - the first guiding research questions were formulated according to the principles of grounded theory (When do you think a person begins to age? What does it mean to grow old? How does it manifest? When and how did you notice that you are getting older? Does old age have any advantages? Disadvantages? etc.). The question "Do you think that your body reflects what you really are?" was intended to help support or refute "old mask" theory. Based on E. Goffman's theory, questions such as "Do others notice your aging? How do they react? Does that hurt you? Why do you think they react like this?", "Have you experienced situations where you felt old or too old? What were they?", "Have you ever felt uncomfortable because of your age and tried to hide it? If so, in what situation?" were included to examine whether old age in everyday interactions is experienced as a stigma. Questions about youthfulness and any measures taken to prolong it ("Do you try to stay youthful? What do you do? Why do you attempt to stay youthful? Is it important to remain youthful in old age? Why?" etc.) examine whether there were identifiable consumerist trends towards youth prolongation as mentioned by M. Featherstone and others.

Sampling and Informants. The qualitative study was conducted by the author from October 2010 - January 2011 in Vilnius. In total, 24 informants were interviewed. In order to cover the widest possible diversity of old age experiences and meanings, selection of informants was targeted by gender, age group (60-74 or 75-89), educational level (primary, secondary, higher), and household type (households of several generations, single-generation 
and institutional households). The search for informants was performed using the personal social network of the author; namely, asking neighbors, friends, relatives and acquaintances to involve their relatives, acquaintances, neighbors and friends, as well as visiting two care homes for the elderly. The characteristics of the informants were close to those desired with the exception of age, which parameters accordingly had to be slightly expanded: one resident of a care home happened to be 58 years old and two 96 years old (see Table 1 and 2).

Table 1. Targeted and actual characteristics of research participants.

\begin{tabular}{|c|c|c|c|c|c|c|c|c|c|}
\hline \multirow[b]{2}{*}{ Gender } & \multicolumn{2}{|c|}{ Age (years) } & \multicolumn{3}{|c|}{ Education } & \multicolumn{3}{|c|}{ Household type } & \multirow[b]{2}{*}{ 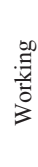 } \\
\hline & $\frac{+}{1}$ & $\begin{array}{l}\infty \\
i \\
n\end{array}$ & $\begin{array}{l}\vec{E} \\
\text { E्E } \\
\text { E }\end{array}$ & 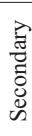 & 离 & 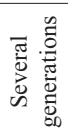 & 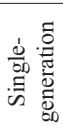 & 吾 & \\
\hline Men (targeted) 12 & 6 & 6 & 4 & 4 & 4 & 4 & 4 & 4 & 3 \\
\hline Men (actual) 12 & 6 & 6 & 2 & 5 & 5 & 3 & 4 & 5 & 3 \\
\hline Women (targeted) 12 & 6 & 6 & 4 & 4 & 4 & 4 & 4 & 4 & 3 \\
\hline Women (actual) 12 & 5 & 7 & 1 & 6 & 5 & 4 & 4 & 4 & 2 \\
\hline
\end{tabular}

Source: composed by the author.

To obtain interviews did not prove to be easy as people frequently refused to take part or changed their minds once they had agreed. Often informants mentioned that the topic of the conversation was unpleasant or painful (for example, I3). There was even a case when the interview had to be stopped (“Oh, God. Stop it, no, I don't want to [...] you are just killing me with such questions", I4) and could be continued only after a longer conversation. While talking about aging, informants eschewed the role of expert and often felt that they were not "the right ones" for the interview, because the topic of aging did not correspond to their lives (I16, I19, I5), and their age was not important. The vast majority of informants (21 of 24) said they were not old, did not feel old (I23) or did not notice their aging. The experience of aging was considered very personal, private and painful, and perhaps concealed from one's self. It was noted that directly-formulated questions were painful; thus the interviewer avoided unnecessarily mentioning the words "old age", "old" and "aging", omitting them where possible and replacing them with a more neutral term ("age") (which is different from "old age" in Lithuanian G.R.), or using the informants' preferred term ("mature person"). 
Table 2. Demographic characteristics of research participants.

\begin{tabular}{|c|c|c|c|c|c|c|c|c|c|c|c|}
\hline \multirow[b]{2}{*}{ 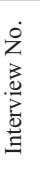 } & \multicolumn{2}{|c|}{ Gender } & \multicolumn{2}{|c|}{ Age (years) } & \multicolumn{3}{|c|}{ Education } & \multicolumn{3}{|c|}{ Household type } & \multirow[b]{2}{*}{$\begin{array}{l}\text { 量 } \\
0 \\
0\end{array}$} \\
\hline & 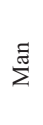 & $\begin{array}{l}\text { ज्ञ } \\
\text { है } \\
\text { B }\end{array}$ & $\begin{array}{l}t \\
\stackrel{d}{0}\end{array}$ & $\begin{array}{l}\infty \\
\vdots \\
n\end{array}$ & 胥 & 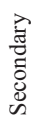 & 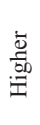 & 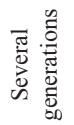 & 总 & 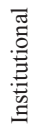 & \\
\hline 1. & & $\mathrm{v}$ & $\mathrm{v}$ & & & & $\mathrm{v}$ & & $\mathrm{v}$ & & \\
\hline 2. & $\mathrm{v}$ & & $\mathrm{v}$ & & $\mathrm{v}$ & & & $\mathrm{v}$ & & & \\
\hline 3. & & $\mathrm{v}$ & & $\mathrm{v}$ & & & $\mathrm{v}$ & & $\mathrm{v}$ & & $\mathrm{v}$ \\
\hline 4. & & $\mathrm{v}$ & & $\mathrm{v}$ & & & $\mathrm{v}$ & & $\mathrm{v}$ & & \\
\hline 5. & $\mathrm{v}$ & & $\mathrm{v}$ & & & & $\mathrm{v}$ & & $\mathrm{v}$ & & \\
\hline 6. & & $\mathrm{v}$ & $\mathrm{v}$ & & & $\mathrm{v}$ & & $\mathrm{v}$ & & & \\
\hline 7. & & $\mathrm{v}$ & $\mathrm{v}$ & & & $\mathrm{v}$ & & $\mathrm{v}$ & & & \\
\hline 8. & & $\mathrm{v}$ & $\mathrm{v}$ & & & $\mathrm{v}$ & & $\mathrm{v}$ & & & \\
\hline 9. & $\mathrm{v}$ & & $\mathrm{v}$ & & & $\mathrm{v}$ & & & $\mathrm{v}$ & & \\
\hline 10. & & $\mathrm{v}$ & & $\mathrm{v}$ & & & $\mathrm{v}$ & & $\mathrm{v}$ & & \\
\hline 11. & & $\mathrm{v}$ & & $\mathrm{v}$ & & $\mathrm{v}$ & & & & $\mathrm{v}$ & \\
\hline 12. & & $\mathrm{v}$ & & $\mathrm{v}$ & $\mathrm{v}$ & & & & & $\mathrm{v}$ & \\
\hline 13. & & $\mathrm{v}$ & & $\mathrm{v}$ & & $\mathrm{v}$ & & & & $\mathrm{v}$ & \\
\hline 14. & $\mathrm{v}$ & & & $\mathrm{v}$ & & & $\mathrm{v}$ & & & $\mathrm{v}$ & \\
\hline 15. & $\mathrm{v}$ & & & $\mathrm{v}$ & $\mathrm{v}$ & & & & & $\mathrm{v}$ & \\
\hline 16. & & $\mathrm{v}$ & & $\mathrm{v}$ & & & $\mathrm{v}$ & & & $\mathrm{v}$ & \\
\hline 17. & $\mathrm{v}$ & & & $\mathrm{v}$ & & & $\mathrm{v}$ & & & $\mathrm{v}$ & \\
\hline 18. & $\mathrm{v}$ & & $\mathrm{v}$ & & & $\mathrm{v}$ & & & & $\mathrm{v}$ & \\
\hline 19. & $\mathrm{v}$ & & $\mathrm{v}$ & & & $\mathrm{v}$ & & & & $\mathrm{v}$ & \\
\hline 20. & $\mathrm{v}$ & & & $\mathrm{v}$ & & $\mathrm{v}$ & & $\mathrm{v}$ & & & \\
\hline 21. & $\mathrm{v}$ & & $\mathrm{v}$ & & & $\mathrm{v}$ & & & $\mathrm{v}$ & & $\mathrm{v}$ \\
\hline 22. & $\mathrm{v}$ & & & $\mathrm{v}$ & & & $\mathrm{v}$ & & $\mathrm{v}$ & & \\
\hline 23. & $\mathrm{v}$ & & & $\mathrm{v}$ & & & $\mathrm{v}$ & $\mathrm{v}$ & & & $\mathrm{v}$ \\
\hline 24. & & $\mathrm{v}$ & $\mathrm{v}$ & & & $\mathrm{v}$ & & $\mathrm{v}$ & & & $\mathrm{v}$ \\
\hline
\end{tabular}

Source: composed by the author.

Analysis of interview content. The main question to be answered from the material collected was: How is old age understood? Content analysis was performed in the usual way using coding; i.e., the interview texts were revised and passages describing old age, aging etc., were selected and grouped together. The largest group consisted of passages in which old age was understood as age expressed in years, or when older people were perceived as a social category. In terms of content, the closest topics (with only few passages) were family, activity, work and friends. The other two thematic groups of approximately equal scope concerned declining health and mental retreat, while smaller groups involved the topics of bodily aging and personal attitudes to aging. The last thematic group was able to unify the approach to old age as a stage of life and time remaining until death. In the following, each of these is introduced in greater detail. 


\section{Old age as chronological age or a social category}

A somewhat abstract question, "When does a human start to age?" was frequently understood by informants as a question requiring an answer in the form of a number of years. Informants would either state their current age (I6, I24), indicate the age at which health ailments or other signs of aging that they identified by themselves had started (I3, I10, I17, I20, etc.), or would say they could not specify a year because different people begin aging at different times:

"And I would like to say that someone at 50 years may already be old and already start groaning, while another at 80 keeps going, doing, handling things; 80 is also relative, if the head and feet work, I do not know, the mind works (I1).

Often, informants compared themselves or their acquaintances with some kind of age norm or an ideal type, saying, for example:

"Well, for a person of my years, I do not feel as old as I am. I think, whether I really am so old. And according to years, and in other ways, and according to my character, according to my nature, I do not feel that I am so many years" (I1).

This age norm or image of an old person lags behind by at least one generation as it is based on childhood experiences: old people usually compare themselves with their grandparents. This results in a mismatch between an "ideal" and a "real" image, which is manifested and is constantly consolidated through everyday interaction:

"Well, they probably want to humor me, but people say that I look younger than I actually am, than my passport says" (I23; as well as I9, I13, I16, I17, I22, I24).

A passport was used as an indication of age more than once (according to Goffman, 1986: 59-61, a document may be an attribute of stigma) as a means of talking about age without actually referring to it directly. Informants usually tried to avoid specifying their age in years during conversation (saying "for my age" as in I1, I8, I20, I24). However, even age itself is referring to behavioral norms related to aging:

"Age is yours, and there is a passport in case you forget it" (I5);

"Well, let's say young employees, just look at the way they view elderly people, what else do you want at the end of life, they say. You are 90 and still thinking of something" (I14).

Correspondingly, the chronological age of an individual appears to wedge one into a frame, despite other attributes (health, physical or mental ability, appearance, activeness, etc.). What is this frame? What are the elderly as a 
social category? In short, they are those who have crossed a line. People at the age of $n$ years are no longer involved in social surveys as their opinion is no longer regarded as important (I1, I23); they are no longer given discounts on medical tests or medications (I1, I10, I8) and even their illnesses are no longer treated as old-age illnesses (I6, I8). The price for necessary medical services sometimes exceeds the "residual value" of a person (I23) and care from medical institutions (has to be) obtained through bribes (I10, I4).

Persons approaching the fatal age margin can no longer get a job (I1, I5, I21, I22, I23) because they are downgraded and considered insufficiently energetic by potential employers (I21); and later, one becomes retired, dependent and no longer interesting to others (I4, I24), pushed away from activity, "rejected" (I7, I17, I20); "one is sidelined" (I5), "feels down", "is brought down" (I4, I7), is "written-off" (I1, I10), "unnecessary" (I5, I9, I20), "overboard", or "out of context" (I4). Some informants underlined the hostility of young people as well as their casual, taunting and depreciating attitude toward the elderly (I1, I8, I10; "Is it normal to mock an old person like that?", I13; I14; I21), formal interaction (I4) as well as the lack of attention from family members (I13) or disregard for the needs of the elderly (I1). The elderly feel used by their families ("we serve someone - grandchildren or children", I1) and society ("they are needed once elections come", I1). Once they become dependent on others they lose in the competition with grandchildren for the attention of middle-aged adults (I13).

The media pays little attention to the elderly ("Well, there are no old people on television; they are old, unattractive, they talk nonsense, they say the wrong things. And look, all the faces are polished", I1; as well as I3, I6, I7, I10, I17, I24); the attention is event-related (I4, I5), mocking (I1, I10) or focuses on poverty alone (I7, I14). Putting it in the words of one informant, "nobody loves old people. Nope. Not even some children" (I6). Only three informants bravely said that the elderly were respected and treated properly (I2, I9, I24), while just two of them said they were portrayed correctly by mass media (I2, I9).

Being old is related to the topics of work, activity, family and friends. The onset of old age is also related to the loss of paid jobs, retirement (I9; I14), the loss of the ability to work (I22; I10), which means a deterioration in economic conditions (I9) or grievances about the unfulfilled promises of employers (I20). The niche of the lost job is filled with another activity. This saves one from old age, as if an active person could not be old:

"Others grow old; a young person grows old faster doing nothing. Sometimes they have no job, no occupation, so they grow old slowly. And others of older age look young because they have some activity like singing, acting or sports, and they don't get old that quickly" (I22, as well as I16). 
Older people accentuate their own or other's occupations and ability to engage in useful activity; for example, women often work at home: bake, cook or knit (I1), while a man serves the women in the family as a driver (I21); some write poetry or publish a bulletin board (I16), paint pictures (I15), make sculptures, accessories (I14), collages (I10), weave baskets (I1), sing in a choir (I1, I22, I23) or recite poems (I16), etc. Activity — paid work or participation in the activities of an organization - becomes a refuge:

"Occupation. The most important thing is occupation. I have long said that if they turn me away, what to do then, what to do? How to get occupied, how to get occupied? One thing, I say, still good is that there is this choir. One way or another, there would be nothing to do" (I21).

The lack of an occupation it is painfully experienced (I24).

One's own family becomes an additional baseline for understanding one's own age...

"Yes, I do feel old (laughing) next to my grandchildren. I feel that I am already old, a grandmother. When the grandchildren were small, that word "grandmother" somehow did not "stick", it seems that... that still n... I did not accept that I was a grandmother" (I24)

..or not accepting it...

"I am still young at heart. I am still raising grandchildren, just born (smiling)" (I10, as well as I13).

One's family, especially grandchildren and great grandchildren, bring meaning to one's life (I9, I14, and I24) and maintain the will to live (I13). The circle of friends of an aging person grows smaller (I20), there are fewer friends who "don't call you a granny (smiling), old lady or nana" (I4), and one increasingly starts longing for the company of close family and friends (I13).

\section{Old age as a decline in health}

The onset of old age is frequently perceived as inseparable from a decline in good health, weakening physical strength and more frequent need for rest (I1, I2, I7, I9, I10, I13, I16, I17, I22, I23) and slower performance (I3, I10, I22, I24). The process of the general decline of health is constant and gradual: informants observe it (I10, I13) and, irrespective of their age, say they have started feeling its impact recently; i.e., one or a few years ago (I3, I7, I9, I13, I23). As informants refer to the weakening of health as the onset of old age, the listener gets the impression that the process of aging has started recently. Perhaps this was the intention the informants wished to portray as it corresponds to a denial of (one's own) old age. Or is such a coupling 
of the two things misleading? On the other hand, both declining health and aging may be profound and coupled at later stages of life; for example, a bedbound woman suffering from constant pain said: "Before I got sick, I did not understand old age. Everything ended once I became sick" (I12). Men who are unable to move independently simply refer to their state by saying "there are many things you can no longer do yourself" (I14) or that a "sedentary life has started" (I17). Possibly, the confusing link that is implied between old age and disease could be explained by the words of one informant:

"old age is no disease (laughing), and say there is a disease, then there is old age and if there is a terminal disease, then old age has started" (I4).

Thus, old age is not considered a disease; however, a more serious disease at an older age does mean old age. Whilst people feel well and mobile, they do not perceive themselves to be old (I4, I5). Disease-related ailments are more frequently coupled with old age (I20); although no specific health issues are associated by informants with aging. For example, only one woman mentioned menopause and urinary incontinence (I6), and only one man named sexual dysfunction (I20), one more mentioned weakening sight and hearing (I23), and one dental and back problems (I23). Two women mentioned physical pain (I10, I12). Thus, the conversations reflect the motif of bodily wear and decline, which is particular to the biomedical discourse of aging (Powell, Biggs, 2003) (I18, I22):

"With age, all organs wear out and a person grows weak" (I11);

"...it is only natural: everything wears out, even metal wears out, never mind a living organism" (I24) -

although not as vividly expressed as in a research of younger women (5157 y.o.) conducted in Great Britain (Ballard et al., 2005).

In the sense of intellectual and mental ability, an old person is perceived as someone who has few interests (I2, I8, I11, I13, I16, I20), is indifferent to the surrounding environment (I4), has no needs and desires (I6, I10, I13, I18, I22), and is even no longer willing to live (I4). Aging people distance themselves from problems of the government (I1) and take no interest in surroundings as nothing can change for them (I2). Differently to what would be expected according to the "mask of ageing" theory, informants said that people also grow old spiritually (I13, I15): their intellectual ability deteriorates (I14) as does their memory (I20); changes can be observed in thinking and speaking (I11, I6). Only one informant referred to aging-related changes positively, observing that the thinking of an old person is more mature compared to that of a young person (I17). Old age is related to a lack of optimism (I4, I23) and playfulness (I4). On a more positive note, such disengagement is also described as the desire to be lazy or do something pleasant, as well as to 
renounce unnecessary things and a decline in responsibility for children and family (I3).

The natural disengagement of old age is discussed in the theory of gerotranscendence (Tornstam, 2005): in older age, the focus of a person shifts from external issues to internal, spiritual and transcendental ones. However, the research data do not indicate such a shift of focus from earthly matters to spiritual ones as only one informant specified that religion was a counterbalance and a solace in old age (I23). This is hardly likely to indicate the triumph of soul/spirit and disengagement from a withering body, the practices of the Self and the "golden age" of care for oneself, as per M. Foucault's "disembodiment" thesis. The mental disengagement mentioned by informants is more reminiscent of depression; however, this supposition could only be confirmed or denied by psychologists or mental health specialists. In the meantime, the ability to maintain interest and needs is an important indication that an informant is not yet old (I3, I4, I10, I11, I13). Informants attempted to contradict the stereotype of an old person (I1, I4, I7, I13) or said they did not match the stereotype (I10) (compare Goffman, 1986:10, on the efforts of a stigmatized person to gain excellence in the area of one's defect; in this case, having an active life is the way to escape ageing).

Thus, chronological age and declining health are among the most important indicators of aging. Meanwhile, the elderly of rural England construct old age differently to young people: they refrain from referring to chronological age and physical abilities but rather underline the importance of having a discerning mind and social abilities (Degnen, 2007). It is possible that residents of Lithuanian towns and villages with closer communities would refer to old age in a similar manner.

\section{Old age as external ageing of the body}

The body is an important signifier of age. Questions about the body are perceived "externally" and usually are followed with a clarifying question concerning whether the interviewer means the body "in terms of years" or based on the opinions of others (as in I13). Meanwhile, the interviewer tried to investigate the personal relationship of informants with bodily ageing.

Excerpts attributed to the topic of external bodily ageing contain the vivid motif of a mirror: a person understands aging only by looking at one's self in mirror (I3, I6, I13, I16, and I21):

"Aging? You know, I can't tell you much as I don't feel it in me. I only see 
what the person looks like in a mirror and... in my heart... I feel the same as in my youth" (I21).

Informants often underline the contradiction between an aging body and ageless heart (I1, I7, I8, I10, I22, I24) or soul (I3, I6, I8, I14), which is mentioned in the "mask of ageing" theory. However, the question "Do you think your body reflects what you really are?", which was included to facilitate confirmation or rejection of the "mask of ageing" theory, was difficult for informants to answer: most did not understand it; other had difficulties in understanding, failed to explain their answers or did not answer at all (perhaps as the question seemed too personal or inappropriate). There were three informants who understood the question at once and supported the contradiction between the body and soul (I3, I14, I21), and there was one informant who did not agree with the contradiction (I7). One should not dismiss the idea that the question could have been difficult to answer due to it being improperly formulated; however, it is likely that the idea of the mismatch between an ageing body and a youthful heart, especially in terms of the indicators used by a contemporary consumer society, is alien to the elderly ("Well, probably. I think, there is no other way", I23). Informants do not use cosmetics to 'maintain' their looks. 17 out of 24 do not use anti-wrinkle creams while two female informants are supplied with such products by their children (I3, I10). Only 5 female informants dye their hair; one perceived hair dyeing to be a hygiene-related norm ("I dye, I dye everything and get my hair cut", I3); another female informant started dyeing her hair as she did not want to be referred to as the "grey" teacher (I10). Women refuse to dye their grey hair as it looks beautiful (I1) or there is "no point" in dyeing (I4) or there is "nobody who would appreciate it" (I13).

Only one informant would resort to plastic surgery, provided she had money (I10); a male informant thought the procedure could be helpful as it acts to rejuvenate (I17); however, most thought it was completely unnecessary (I2, I4, I5, I7, I8, I9, I15, I24) as it was a short-term measure, or hardly effective (I6, I11, I13, I14, I22). They also spoke up for natural looks (I16, "how could one be with somebody else's face", I3, "every age is beautiful in its own way", I23); the way it is intended by God or nature (I7, I18, I20, I21). Thus, older people do not use cosmetic products as an individual strategy to avoid old age stigma. Moreover, only one (the youngest) male informant mentioned grey hair as an indication of old age (I18), while nobody mentioned wrinkles. Naturally, the question arises whether the old age attributes accentuated in the scientific literature may only be important to younger people. As the data from this piece of research indicate, the ageing experience characterized by old people themselves does not have space for such attributes. 
Somewhat unexpectedly, an inability or unwillingness to look after one's body was identified as an indication of old age. In this respect, "old" is quickly coupled with "sloppy", "unkempt", dirty hair (I13), "bedraggled" (I16), "ragged" (I11), "dirty"; carelessly wearing a bathrobe and mismatching shoes (I16): i.e., no longer conforming to the standard of femininity. Consequently, clothes can help one stay youthful (I24, I11). In this respect, the choice of clothing is related to efforts to "keep tidy" and "keep up" (I1, I24), to stay trendy and blend in (I13, I20, I22) or to look more dignified and serious (I6). Other informants said they did not consider their age too much (I16, I21) but rather tried to make sure their clothes and shoes were comfortable (I3, I7, I23), clean and tidy (I9). Some informants said there was no point in caring about clothing (I4, I14). In terms of corresponding to social norms, caring about one's appearance would be closer to the concept of "social mask" rather than the "mask of ageing"; however, appearance does not necessarily include the means of rejuvenation, which are underlined by both theories.

Other ways of caring for one's body, such as sports, exercising or having a healthy lifestyle, are usually perceived as health-strengthening measures and are used in moderation. When asked about exercising, informants mentioned all types of activities, including walking (I2, I4) and gardening (I9). 10 informants said they were engaged in sports or exercising; they usually had in mind a short session of exercises in the morning (e.g. 20 minutes before breakfast, I24) or exercising in bed (I14, I15). It is likely that this kind of care for one's body is a lifetime habit as only one informant was a former athlete and took exercising seriously (i.e. dedicated one hour to exercise on a daily basis, I5) while another informant has been doing a certain routine of exercises for 20 years (I23); one follows a diet together with his wife, as well as tries to lead a healthy lifestyle (I23); meanwhile, one informant said she follows a diet to control her weight (I24). In the latter cases, similarities could be found with the reflective project of the Self by A. Giddens which was observed also in a Swedish piece of research (Öberg, Tornstam, 2001). However, the frequency in Lithuania (13 percent in this particular survey; all informants had been through higher education) would possibly be smaller than those from Sweden (62 percent of respondents). In general, ageing is not considered to be a reason to undertake serious efforts to rejuvenate one's body or change one's life in a more radical manner. Informants underlined that "one should look after oneself for reasons other than beauty", only "for the sake of hygiene" (I15). 


\section{Old age as a contrast to youthfulness}

Although the majority of informants said it was important to remain youthful, their perception of youthfulness hardly corresponds to the conception that is specified by western theoreticians: i.e. "extended youthfulness", achieved with the help of technologies and discipline, which is characteristic of a consumer society. It is important to remain youthful because it makes life "easier for those around you and yourself" (I1, as well as I5, I8) as an older person stays interested in the surrounding environment, reads, and even learns new languages (I1, I17), keeps up with life (I2, I11), participates in the life of society (I5, I13, I16), finds a common language with young people (I21), is playful, knows how to laugh at oneself (I4, I14), is neat (I13, I16), industrious, creative (I14), even takes care of one's self and requires no external assistance (I9, I14, I20). Only three informants mentioned the importance of looking young (I10, I22, I24). Strictly speaking, a youthful person is "longer regarded as a human being. Otherwise, they think you are a wreck" (I10).

Some informants regard the importance of youthfulness reservedly, "trying to not overdo it" (I3), do it "sensibly" (I23, as well as I6, I15, I16, I20, I21, I22), making an effort to feel better and have better health (I5, I15, I23) or think that staying youthful is an impossible task as youth and health cannot be regained (I2, I6, I9, I10, I12, I13, I19).

The relationship of informants to ageing varies from lightly positive ("Maybe even old age is a beautiful stage of this life", I9) to strongly negative ("You are killing me with such questions", I4). Opinions may be unnamed and unformed (I8) or neutral (I3). Still, old age is more frequently perceived negatively: it is painful (I13), nobody waits for it (I11), it is something to be afraid of even if it is beautiful and prosperous (I24). Sometimes it is hard to own up to the number of years one is (I24) and joy is expressed that people "don't give more" (I5) or an informant looks younger (I13). Still, one would like to be younger (I24). In this context, there is an exception with those over 90: one can feel that these people are proud of their age (I15, I17). It is hard to say whether such a perception comes with age and indicates the profound maturity of a person, or whether there is an essential difference in the attitudes of generations towards old age.

\section{Old age as a stage of life}

Old age emerges only in some interviews as a stage of life and a natural continuation. The emphasis is usually placed on experience gained (I14, I23) 
or remaining earlier interests (I1, I23). In addition, some informants observe that old age is the outcome of an earlier life (style) (I1, I15), when an entire life is scrutinized (I17, I22). Two informants also noted that there is nothing particularly special about old age as a person changes many times during the lifetime (I21):

"My life moved together with life. It changed more than once"(I15).

Conversations also touched upon the topic of old age as the time left before death. Similarly, it was mentioned in a neutral manner: as a natural process (I9, I15, I22, I11) which needs to be accepted (I1, I21), the understanding of which changes one's relationship to everyday issues ("Nobody can take anything, truly speaking", I1). Sometimes it is perceived positively ("Still, you continue growing until the journey beyond", I14), with light humor ( "... at this age, we have already given up many things, many of us are already having tea with Abraham, well, and I somehow stayed behind", I23) but it is also seen negatively, with informants stating that life has already passed (I14, I17) and the finish line is getting closer (I23), thus, all that is left is to wait for it (I20), be scared (I24) or desire it (I9) as there is no hope left (I4, I13).

\section{Old age as a stigma}

The research was also designed to find out whether old age was a stigma and whether people felt stigmatized in their daily interactions and tried to escape it. 14 informants said they did not feel they were treated differently because of their age as their aging remained unnoticed, or at least unmentioned by others. Related comments were usually made by family members, namely spouses (I9, I20, and I21) and children (I2, I3) as well as friends (I5, I8, I21). Usually, such comments are not taken personally or are simply ignored (I2, I9, I18, I20, I21); nevertheless, receiving a positive and supportive reaction was mentioned only once (I3). Still, during an interview the informant usually expected the interviewer to acknowledge that s/he was not old yet (I8, I9) or remembered an analogous case when the old age of the informant was negated by her grandchild (I10).

Although only two painful reactions toward the environment were identified (I10, I14), one female informant remembered being discriminated against on the grounds of age at an outpatient clinic (I10), some witnessed disrespectful treatment of the elderly (I7, I14), and others noticed they felt uneasy in public, especially among young people (I1, I6, I7, I10), which resulted in them avoiding going out (I10) as well as meeting new people just to avoid possible disrespectful behavior (I4). Only one informant mentioned being welcomed 
by groups of people due to his well-trained voice (I23). Sometimes it was underlined that a particular person was capable of interacting with young people and was therefore accepted (I1, I8). Consequently, young people are one of the stigma factors. According to E. Goffman (1986: 107), such arguments are used to get rid of stigma while treating the more obviously stigmatized with attitudes particular to "everyday people"; i.e. such kind of arguments that were used in his/her own case as there are always others to whom the stigma seems more applicable.

Situations in which a person feels old or too old are usually related to their reduced opportunities and diminishing strength (I4, I14, I17, and I20); thus withdrawal seems to emerge from within a person. Nevertheless, this mirrors internalized age norms that regulate power relationships ("know your place", I3; "being this old it is better to stay quiet", I13, I14): e.g., a working woman giving up her leadership position for the benefit of younger female colleagues (I3), another deliberates what is appropriate (I13), the third feels old when referred to as a grandmother but would not desire to be called differently as it would "not look very good" (I24). Sometimes conflicts with the surrounding environment arise from attempts to force someone to behave age-appropriately (I16, I21).

The absolute majority of informants said they did not try to disguise their age (I1, I15, I17, I19, I21, I22, I23) as such efforts seemed vain or pointless ("Well, I am what I am. People must accept me", I3, also in I4, I5, I9, I10, I13, "it is impossible to hide something that is unhidable", I14, "What's the point in hiding? How would you hide it? It will still be visible. What is there to hide? " I16, I18), and only one informant acknowledged that she disguised her changing body under looser clothes (I6), while another said she struggled to state her age (I24).

Thus, aging is marked by chronological age. It means loss of social status and value, declining health and social roles limited to family. However, the relationship with aging is ambiguous. Old age might not appear to be stigmatized in everyday interactions as informants did not conceal their age and yet still received no negative reactions related to age from their environment. However, if old age is not stigmatized, how can we explain the following aspects of aging experiences revealed during the interviews? Older people were reluctant to talk about aging and their experience of aging, they did not identify themselves with old age, and this topic was painful to them; they felt hurt if they were categorized as old people (granny, senior, etc.), which would put them "behind the line" in many aspects; in everyday interactions the denial of old age ("you don 't look old", excitement about youthful appearance, etc.) seemed deeply rooted; informants avoided specifying their years during the 
conversations; they tried to deny the abstract stereotype of an old person or to object to being categorized as an old person ("I'm not old", "I don 't feel old", etc.) and expected approval from the surrounding environment that the person was not old. The social category "old people" is not applied to themselves or their peers but rather to strangers of the same age (I8). The elderly behave according to internalized, marginalizing norms: they stay quiet, give up leadership positions, etc. Older people said they avoided strangers and felt uncomfortable in public, especially with youth; or conversely, stressed that a particular person was able to communicate with young people and was therefore accepted. On the grounds of age, people felt discriminated against by public opinion researchers, medical staff, employers and family members; additionally, they felt ignored by the mass media.

In the sense of E. Goffman, old age has definite features of stigma. However, the denial of aging or old age, as well as resistance to it, indicates ageism: "The simple fact that these forms of resistance exist suggests there $i s$ something out there to avoid and that there are powerful constraining forces at work" (Link, Phelan, 2001: 378). The attempts to avoid the stigma (thus to belong to the majority), to be an exception to old age stereotypes as well as the refusal to identify oneself with old people and recognize one's own age only confirm the existence of stigmatization because denial would not be required if the stigma were nonexistent. Efforts to avoid stigma lead to an undignified condition characterized by self-denial and secret self-disgust (Falk, 2001:129,134-135).

The analogous denial of old age was discovered in the study "University of Third Age" in Poland and explained using their ideology (Wilinska, 2012); however, as the results of this study show this denial is also prevalent among the elderly that do not belong to any organization. Previous research in Lithuania also revealed that age discrimination is more often recognized and identified with the help of specific questions as people don't usually tend to reflect on such experiences or agree to make them public (Mikulioniené, 2008). This indicates unconscious ageist attitudes that are active in Lithuanian society.

Thus, the results of this study show that old age is a social construct, filled with negative rather than positive content on both the social (labor market, medicine, and media) and individual level (declining physical and mental health, external body aging). The dominant theories about old age identity do not fully explain the phenomenon captured in the data collected for this study. Albeit, the opposition between having an old body and a young heart was discovered, which is suggested by "old age mask" theory; informants also recognized the ageing of the human spirit. Presumably, the tension caused by 
an ageing body (as suggested by "old age mask" or "social mask" theories) should manifest itself in consumerist efforts to "prolong youth"; however, evidence to support this proposition could not be empirically grounded. Only efforts to conform to social norms of appearance and to remain a fullyfledged member of society were identified, which is more contiguous with the concept of stigma. Contrary to mainstream statements in the literature about ageing identity, older people did not consider wrinkles and gray hair to be important signs of old age. Only fragments of manifestations of the reflexive project of the Self by A. Giddens as well as the "disembodiment thesis" by M. Foucault were discovered. There is no reason to maintain that the conscious inclusion of the ageing body into the project of the Self or Self technologies as ways of self-realization in old age are characteristic to the ageing identity of contemporary Lithuania. The main thesis of gerotranscendental theory which alleges that an ageing person focuses on the internal world, spirituality or nature, was found to have no basis in reality in this study, either. Although there exists ambiguity, which may be explained by theoretical insight, E. Goffman's concept of stigma seems to be most suitable for explaining old age identity in Lithuania: namely, the social construct of old age is so abhorrent and marginalizing that people avoid identifying with it. 


\section{REFERENCES:}

Ballard, K., Elston, M.A., \& Gabe, J. (2005). Beyond the mask: women's experiences of public and private ageing during midlife and their use of age-resisting activities. Health, 9, 169-187.

Biggs, S. (1996 (1993)). Understanding ageing. Images, attitudes and professional practice. Buckingham: Open University Press.

Biggs, S. (1997). Choosing Not To Be Old? Masks, Bodies and Identity Management in Later Life. Ageing and Society, 17, 553-570.

Biggs, S. (1999). The Mature Imagination: Dynamics of Identity in Midlife and Beyond. Buckingham: Open University Press.

Degnen, C. (2007). Minding the gap: The construction of old age and oldness amongst peers. Journal of Aging Studies, 21, 1, 69 - 80.

Dey, I. (2004). “Grounded Theory” In Qualitative Research Practice, ed. by Seale, C., Gobo, G., Gubrium, J.F., Silverman, D. London, New Delhi: Sage Publications.

Falk, G. (2001). Stigma: how we treat outsiders. N.Y., Prometheus Books.

Featherstone, M., \& Hepworth, M. (1990). Images of ageing. In Bond, J. and Coleman, P. (ed.) Ageing in Society. Sage, London.

Featherstone, M., \& Hepworth, M. (1991). The Mask of Ageing and the Postmodern Lifecourse. In M. Featherstone, M. Hepworth \& B.S. Turner (eds.), The Body: Social Process and Cultural Theory (pp.371-98). Thousand Oaks, CA: Sage.

Featherstone, M., \& Hepworth, M. (1993). Images in Ageing. In John Bond, Peter G. Coleman, and Sheila M. Peace, Ageing and Society (pp.144-167). London: Sage.

Featherstone, M., \& Wernick, A. (1995). Images of Ageing. London: Routledge.

Foucault, M. (1988). Technologies of the Self: A Seminar with Michel Foucault. Luther H. Martin, Huck Gutman and Patrick H. Hutton (eds.). London: Tavistock Publications.

George, L. K. (1998). Self and Identity in Later Life: Protecting and Enhancing the Self. Journal of Aging and Identity, 3: 3.

Giddens, A. (1993). Modernity and Self-Identity: Self and Society in the Late Modern Age. Cambridge: Polity Press.

Goffman, E. (1986 (1963)). Stigma: Notes on the Management of Spoiled Identity. New York: Touchstone.

Harman, G.H. (1965). The Inference to the Best Explanation. The Philosophical Review, 74 (1), 88-95.

Hepworth, M. (1991). Positive ageing and the mask of age. J. Educational Gerontology. 6.2, 93-101.

Link, B.G., \& Phelan, J.C. (2001). Conceptualizing stigma. Annu. Rev. Sociol., 27, 363-85.

Machat-From, L. (2010). 'An ethnic lens on age identity: Identity research in gerontology and migration and ethnic studies', presented in ISA World Congress of Sociology "Sociology on the Move", 11 - 17th of July 2010 in Gothenburg, Sweden. 
Mikulionienè, S. (2008). Diskriminacijos dèl amžiaus samprata viešajame diskurse: asmenų, dirbančių viešajame sektoriuje, atvejis. Socialinis darbas, 7 (1).

Öberg, P. (2003). Images Versus Experience of the Ageing Body. In Ageing Bodies: Images and Everyday Experience, ed. Christopher A. Faircloth (pp. 103-139). CA, Walnut Creek: Altamira Press.

Öberg, P., \& Tornstam, L. (2001). Youthfulness and Fitness - Identity Ideals for All Ages? Journal of Ageing and Identity, 6 (1), 15-29.

Phillipson, C. (1998). Reconstructing Old Age. London: Sage.

Phillipson, C., \& Biggs, S. (1998). Modernity and Identity: Themes and Perspectives in the Study of Older Adults. Journal of Ageing and Identity, 3, 1.

Powell, J.L., \& Biggs, S. (2003). "Foucauldian Gerontology: A Methodology for Understanding Aging“, Electronic Journal of Sociology. Available at: http://www. sociology.org/content/vol7.2/03_powell_biggs.html.

Tornstam, L. (2005). Gerotranscendence: A Developmental Theory of Positive Aging. N.Y.: Springer Publishing Company.

Turner, B. S. (1995). Ageing and identity: some reflections on the somatisation of the self. In Featherstone, M. and Wernick, A. Images of Ageing. Routledge, London.

Wilinska, M. (2012). Is There a Place for an Ageing Subject? Stories of Ageing at the University of the Third Age in Poland. Sociology, 46, 290-305.

Woodward, K. (1991). Ageing and Its Discontents. Indiana: Indiana University Press 